\title{
La fusión de las cooperativas: las expectativas de gestión relacionados con los indicadores financieros
}

\author{
Roque Alberto Zin ${ }^{1}$
}

Recibido: 4 de agosto de 2016 / Aceptado: 2 de junio de 2017

Resumen. ¿Las cooperativas tienen las mismas motivaciones de las otras empresas para llevar a cabo una fusión? Con este objetivo se realizó el presente estudio. Empezó con la fusión de cinco cooperativas con las siguientes características: las asociaciones de agricultores, pequeñas empresas, que pertenece al mismo sector industrial, con productos y mercados similares. Con base en la teoría, un cuestionario con escala tipo Likert de cinco puntos fue desarrollado con el fin de verificar las hipótesis más citados en la literatura. Los cuestionarios fueron respondidos por los gerentes que tomaron la decisión de fusión y participaron en todo el proceso. Los resultados de la hipótesis se compararon con los indicadores financieros de la empresa y confirmaron la opinión de los gestores.

Palabras clave: Cooperativas; Fusiones y adquisiciones; Motivaciones; Gerentes.

Claves Econlit: G30; G34; Q13.

\section{[en] The merger of cooperatives: expectation of managers and their relation to financial indicators}

Abstract. Do the cooperatives have the same motivations as other companies to carry out a merger? With this we performed the present study. It starts with the merger of five cooperatives with the following characteristics: farmers' associations, small businesses belonging to the same industrial segment, with similar products and markets. Based on the theory a questionnaire with Likert-type five-point scale was developed in order for the verification of the hypotheses most often cited in the literature. The questionnaires were answered by the managers who made the merger decision and participated in the entire process. The results of the hypothesis were compared with the financial indicators of the company and confirmed the opinion of managers.

Keywords: Cooperatives; Merger and acquisition; Motivations; Managers.

Sumario. 1. Introduction. 2. Cooperatives. 3. Literature review. 4. Methodology. 5. Hypotheses. 6. Description of the market and the companies. 7. Research methodology. 8. Analysis of results. 9. Conclusions. 10. References.

Cómo citar: Zin, R.A. (2017) The merger of cooperatives: expectation of managers and their relation to financial indicators. REVESCO. Revista de Estudios Cooperativos, $\mathrm{N}^{\circ} 125$, pp. 243-259. DOI: 10.5209/REVE.57062.

$1 \quad$ Universidad de Caxias do Sul, Brasil

Dirección de correo electrónico: razin@ucs.br 


\section{Introduction}

Mergers and Acquisitions (M\&A) are part of the business scenario and their motivations challenge the researchers. Initially, there was the belief that they were waves, a natural phenomenon that occurs in certain periods due to the conditions of the economic environment. However, merger movements keep on happening with variations in intensity and present many different motivations.

Despite the diversity, the main reasons are put into two main lines: maximization of the shareholder value and maximization of the managerial utility. Amid these lines, there are market drivers that can interfere in the motivations of each one of them, named environmental factors.

As mergers and acquisitions take place and researches increase, new reasons for their occurrence are discovered. Seth, Song and Pettit (2002) argue that the main reasons can be placed in three categories: synergy, managerial motivation and pride. Trautwein (1990) proposed seven theories to explain the reasons: efficiency, monopoly, appreciation, empire building, process, burglar and disorder.

The financial literature stated for some time that the main consequence would be the increase of market power, however studies of Jensen and Ruback (1983) and Prager (1992) find no evidence of this increase in power. On the other hand, Kim and Singal (1993) confirm this occurrence in the concentration of aviation companies. The divergent results lead to further studies in search of motivations and results. While doing their literature review, Haleblian et al. (2009) present four factors for the movements of mergers and acquisitions: creating value, managerial interest, environmental factors and company characteristics.

Despite the variety of empirical studies on the phenomenon, Meglio and Risberg (2010) criticize most researchers which utilize similar methods and are based on U.S. occurrences. Such studies are based on secondary data that result in every kind of variables, generally published in U.S. magazines.

There are a lot of studies on company mergers, but a few of them are held in cooperatives. The reasons for this can occur for several factors, amongst which we can mention: such event in production cooperatives does not occur frequently. When such an event occurs, it is very difficult to obtain financial information because it is a private company and does not have to disclose the information outside of the board of associates. This study aimed to fill the gap in studies and investigate the merger of five cooperatives with similar and peculiar characteristics: they are small companies and operate in the same industrial segment. Instead of analyzing economical reasons, the study sought to understand the motivations for merger. The method utilized was interviewing the managers involved in the whole process, since the merger decision until its consolidation.

The questions that guided its preparation were in order to understand why companies of the same segment which produce similar products performed merging. What is the managers expectation in merging? Because of these, a questionnaire about the reasons that led to merging was elaborated, approaching four points widely studied in literature and which were consolidated in the following aspects: market power, scale economy, complementary resources and corporate benefits. Five directors of the companies that participated in the process were interviewed. Data were analyzed by using nonparametric statistics where the 
interviewee's opinions were evaluated in order to identify the main drivers that led the processes. After evaluating the hypothesis, the result was compared to a financial index that would reflect in numbers the opinion of managers. The paper is structured as follows. After this introduction, a literature review on merging, incorporations and cooperatives will be taken. Then, based on literature, the hypotheses were elaborated. After that, the research methodology is described, data is analyzed and final comments are made.

\section{Cooperatives}

The formation of a cooperative enterprise has different motivations and characteristics in relation to traditional companies. According to Drimer and Drimer (1973) cooperative formation has as principle the solidarity economy and promotes the values of mutual aid, solidarity and cooperation among members and among cooperatives.

As Cook (1995) states, the cooperative principles create a capital structure with distinct characteristics from other companies, with control being performed by the associate and not proportional to the capital (one man, one vote) and by the objectives aimed at members rather than maximizing profit.

Among the main differences in a cooperative and other companies, Zylberstajn (1994) points out that there is a complete separation between control of the company and its property, which often the cooperated is the financier of the company, waiting to receive its rights and its capital share. Besides, according to Zylberstajn (1994), the share of each member is unremunerated and has no market liquidity.

Servos and Calderón (2013) state that the main aspects that differ cooperative companies from other companies are related to five dimensions, as shown in Frame 1:

Frame. 1. Differences between capitalist companies and cooperative.

\begin{tabular}{|l|l|l|}
\hline Dimension & Investor Owned Firms & Cooperative \\
\hline Linkage to the group & $\begin{array}{l}\text { Equity stake in the } \\
\text { company }\end{array}$ & Cooperative activity \\
\hline Justification for the & $\begin{array}{l}\text { Maximizing of benefits to } \\
\text { equity suppliers }\end{array}$ & $\begin{array}{l}\text { Creation of collective } \\
\text { value focused on } \\
\text { sustainability }\end{array}$ \\
\hline Motivation scheme & $\begin{array}{l}\text { Economic motivation. } \\
\text { Alignment of individual } \\
\text { interests to organizational } \\
\text { aims ans }\end{array}$ & $\begin{array}{l}\text { Economic and non- } \\
\text { economic motivation. } \\
\text { Common interest as a } \\
\text { basis for grouping }\end{array}$ \\
\hline Governance structure & $\begin{array}{l}\text { Hierarchical approach } \\
\text { when making decision }\end{array}$ & $\begin{array}{l}\text { Democratic approach } \\
\text { when making decision }\end{array}$ \\
\hline
\end{tabular}




\begin{tabular}{|l|l|l|}
\hline Use of surplus & $\begin{array}{l}\text { Dividend distribution or } \\
\text { reserve accumulation }\end{array}$ & $\begin{array}{l}\text { Result division with } \\
\text { obligation to maintain } \\
\text { reserve funds and } \\
\text { education, interest } \\
\text { payment or distribution } \\
\text { by price }\end{array}$ \\
\hline Structure of employees & $\begin{array}{l}\text { Contracts of employment } \\
\text { under wage and } \\
\text { subordination }\end{array}$ & $\begin{array}{l}\text { Workers under wage in } \\
\text { agricultural cooperatives } \\
\text { and partner worker in } \\
\text { cooperative if labor is } \\
\text { associated }\end{array}$ \\
\hline
\end{tabular}

Source: Servós and Calderón (2013)

Market dynamics with new production methods, new market niches and changes in consumption patterns have required increase efficiency from organizations in order to compete in the market. This reality affects all organizations, especially cooperatives. This means that the union of people around the cooperative is not enough, but the integration and/or cooperation among cooperatives, this being the probable cause for the occurrence of mergers among cooperatives.

From Schneider's (2012) point of view, cooperatives should seek integration in different ways, as well as in different levels and degrees, at risk of losing their strength and be limited to marginal spaces in the economic context, leaving the best segments to other companies.

\section{Literature review}

Do cooperatives have the same motivations of other companies to become involved in a merger process? Devos, Kadapakkam and krishanamurthy (2009) emphasize that there is little evidence in literature about the relative importance of underlying sources in gains from mergers. The authors measure three potential gains to shareholders from mergers: operational efficiencies, tax reasons and market power in the case of companies of the same segment.

In a sample of 264 mergers in the U.S. market from 1980 to 2004, it was concluded that the overall average gain from mergers was $10.03 \%$ in the equity value of companies. $1.64 \%$ of this percentage refers to tax savings and $8.38 \%$ refers to operational synergy gains. The gain in market power does not seem to be relevant. The synergy gains represent a large portion of the gain of mergers among companies of the same segment, since the tax gain represents the greatest portion of the gain in mergers of companies from different segments.

Bradley, Desai and Kim (1988) measured the gains from synergies in the acquisitions, in addition to examining the factors that divide these gains among shareholders of the two companies involved. In a study of 236 U.S. companies in the period from 1963 to 1984 it is concluded that the average gains were $7.4 \%$ in the value of the companies involved in the process. This study provides theoretical 
and empirical evidence that a possible competition between companies interested in target company rises its paybacks while decreases the paybacks of acquirer companies.

According to the work of Seth, Song and Pettit (2002) that sought to determine the gains in mergers and acquisitions of companies, the results show that in some types of mergers and acquisitions there was a creating value, the transactions between the related companies apparently did not create more value than mergers and acquisitions between unrelated companies, although the synergy factor presented in these was much smaller. Accordingly, the authors found evidence that there is value creation by scale economy, operational efficiency and market power in mergers and acquisitions involving companies in other countries. Even though other motivations might be considered, there is strong evidence of synergy gains and reduced risks.

According to Brealey and Myers (2006), among the sensible reasons for mergers and acquisitions are: scale economy, use of additional resources, tax savings, use of surplus funds, inefficiency reduction and diversification.

According to Haleblian et al (2009) the financial literature was the first to exploit that market power is the main motivator. The premise is that company reduction allows increasing price level. However, subsequent research found no support for this hypothesis. Prager (1992) and Kim and Singal (1993) find divergent results, thus there is limited evidence to support this hypothesis.

Acquisitions can facilitate reallocation of assets and gain economical advantages of transferring skills and technology. Puranam and Srikanth (2007) show that acquisitions increase the innovative capacity of independent units.

Some studies suggest that acquisitions can discipline managerial inefficiencies. According to Rhodes-krop and Robinson (2008) there is strong evidence that similar companies, but with a high market value, tend to buy companies with low value.

Bena and Li (2014) studied the relationship between patent portfolios and research and development spending. They show that synergies in innovation capacity are important factors driving mergers and acquisitions.

Some researchers argue that mergers occur more in the interests of managers than because of the return to shareholders. Malmendier and Tate (2008) argue that managers are interested in increasing the size of the company to obtain higher remuneration. They conclude that managers pay excessively high amounts for target companies and thus destroy value.

Ambrose and Megginson (1992) find that the issuance of preferred shares decreases the likelihood of the company being acquired, even if this defense tactic results in loss to the shareholder. Cail and Vijh (2007) conclude that the executives with the highest number of unqualified shares feel more motivated to sell the company.

According to agency theory, the difference between ownership and compensation of managers can interfere with alignment of interests and be related to acquisitions. Grinstein and Hribar (2004) conclude that the managers with greater power on the boards received bonus of bigger acquisitions, even if this does not find relation in the stock price. 
The market seems to value the expertise and knowledge of the target company executives. According to Saxton and Dollinger (2004) the exchange of executives after the acquisition adversely affects the performance of the shares of both the acquired company and the acquirer.

\section{Methodology}

Why do two companies decide to join a new organization? Would cooperatives have the same motivation as other companies, even if the pursuit of profit is not the main objective? To analyze the event hypotheses were formulated according to what predicts the literature of merger of companies. Among the main reasons are; Increase market power. Get economies of scale. Complement the resources of each company. Get other corporate benefits. Based on this literature, a questionnaire was prepared to interview the directors of the cooperatives. Next, the opinion was compared with the financial indicators of the companies. Table 2 shows the relationship between the hypotheses investigated and the financial indicators.

Table. 2. Relationship between financial hypotheses and indicators

\begin{tabular}{|l|l|}
\hline HYPOTHESIS & FINANCIAL INDICATOR \\
\hline The new company will have more market power & Profit on sales \\
\hline The new company will achieve economies of scale & Turnover of total assets \\
\hline The merger will enable additional resources to be & Stock Turning \\
\hline The merger will bring corporate benefits & Financial Leverage \\
\hline
\end{tabular}

Source: prepared by the authors

\section{Hypotheses}

Excluding managerial motivations, Haleblian et al (2009) summarize the motivations into five dimensions: market power, which includes gains from synergies and competition reduction; scale economy, which includes an increase in volume production and cost reduction and complementarity of resources, which may be due to better use of assets, synergies, innovation, among others. Other corporate benefits may include tax earnings, use of idle capacity and better utilization of financial resources. 


\subsection{Market power}

According to Porter (1980), the competitiveness of a company depends on five forces of the external environment: rivalry among existing competitors, possibility of new entrants, threat of substitute products, bargaining power of clients and bargaining power of suppliers.

To Ansoff (1977), one of the ways the company might increase its competitiveness may be by increasing the line amplitude, so it opens up new performance opportunities. Another point involves diversification of products and markets, as well as it may gain competitive advantage by defining its most attractive features between price and quality.

Hypothesis 1 was elaborated based on those considerations: the new company will have more market power.

The indicator to evaluate this hypothesis was the return on sales, as Ross, Westerfield and Jaffe (1999) this indicator shows the company's ability to produce low-cost or market a product with high price.

\subsection{Scale economy}

According to Brealey and Myers (2006), scale economies justified the bank concentration occurred in the $90 \mathrm{~s}$ in the United States. The same reason was proven in mergers occurred in the oil industry. The increases in productivity in companies were proven by McGuckin and Nguyen (1995).

Ingham, Kran and Lovestam (1992) identify the main economical and financial reasons for the occurrence of joining companies, including the ones as follow: expectation of increasing profitability, scale and scope economies, risk reduction and cost reduction.

DeMarzo and Berk (2009) state that scale economies come from the volume of production and the elimination of overlapping tasks, such as distribution and sales.

Hypothesis 2 was elaborated based on those arguments: the new company will obtain scale economies.

The financial indicator to evaluate the company's performance was the equity turnover, which according to Demarzo and Berk (2009) shows the efficient use of assets to generate sales.

\subsection{Complementarity of resources}

Some companies can be acquired due to the resources they have and the lack in the acquiring company. The development of these resources can delay and the fastest way to obtain them is by acquiring or joining a company that owns it. Thus, according to Grinblatt and Titman (2005), several studies prove that operational synergies occur in mergers which exceed the cash flows generated by the companies. Acquisitions facilitate the reallocation of assets and transfer of skills can generate economies.

Puranam and Srikanth (2007) show that leveraged buyouts designed for innovative companies increase the innovative capacity of independent units. The results are consistent with the research of Lubatkin, Schulze and Mainkar \& 
Coterril (2001), demonstrating that the market positioning and the resources of the companies involved in acquisitions have influence on its market performance.

According to King, Slotegraf and Kesner (2008), the complementarity of resources of the acquired companies are associated with abnormal paybacks. The study in technology companies reveals that operational resources such as marketing positively reinforce the technological resources.

Hypothesis 3 was elaborated based on those arguments: additional resources will be obtained with the merger.

The complementarity of resources can result in more efficiency, to evaluate the performance of companies was calculated inventory turnover in days.

\subsection{Other corporate benefits}

A merger can occur for tax benefits, including the use of operating losses which can be used to reduce the tax payments of the new company, as well as the use of spare debt capacity and the use of surplus funds. According to Devos, Kadapakkam and krishanamurthy (2009) the ability to leverage the benefits of the target company might be attractive to the acquiring company.

Hypothesis 4 which may be tested, is: the merger will bring corporate benefits.

The indicator to compare with this hypothesis was the financial leverage measured by debt capital percentage in relation to equity. According to Ross, Westerfield and Jaffe (1999) the use of debt can generate more results for shareholders without the investment of equity.

\section{Description of the market and the companies}

The business market is dominated by companies located in the center of the country (São Paulo). The production is mainly carried out in the south of the country by capitalist enterprises, with approximately 500 companies. Only ten cooperatives acted in this market, with the decision of five of them to join to form a single cooperative six cooperatives remained in this segment. Thus, despite the small number, the sample is significant because it represents $50 \%$ of the cooperatives that operated in this segment. The market is for seasonal products, the harvest occurs only once a year, the cooperatives receive the production of the associates and process the products that will be marketed during the course of the year and the following year.

The companies that participated in this study are identified in Table 3 by the numbers 1-5. In order to preserve the identity of the companies and the research participants the names were omitted. In the market, the company performance can happen by two ways: by commercializing their products with their own brand. To do so they need to have a team of sales and a distribution system, as well as communication with the market and other related activities. Another way is by just elaborating the product that will be sold in bulk to other companies. These, in turn, will pack the product in containers of various types and commercialize with their own brand. These companies may have a leaner structure, with no commercial area, no investment in equipment to pack and no distribution structure. 
Table 3 shows the main characteristics of the interviewed companies. As it can be seen, they are small companies, both in number of employees and in value of annual sales. One company has only 8 active clients which shows a high concentration of clients, while another company has 2,212 clients. The concentration of sales is another aspect that can be observed, even though the two companies have not responded how many clients represent the largest percentage of sales, we can see that a company commercializes $90 \%$ of production to only 2 clients and another one commercializes only $26.46 \%$ to only 5 clients. Regarding the type of products, we have a wide disparity among the companies, stating one that claimed to have only 1 product, while the others have 3,4 , and 18 items that are commercialized and, finally, another one has 231 products in its catalog.

Table. 3. Characteristics of the companies

\begin{tabular}{|c|c|c|c|c|c|}
\hline $\begin{array}{l}\text { INDICATOR } \\
\text { / COMPANY }\end{array}$ & 1 & 2 & 3 & 4 & 5 \\
\hline Active clients & 162 & 198 & 60 & 8 & 2212 \\
\hline $\begin{array}{l}\text { Sales } \\
\text { concentration } \\
\text { (clients / \% of } \\
\text { sales) }\end{array}$ & $15=85 \%$ & NR & $2 / 90 \%$ & NR & $5=26.46 \%$ \\
\hline Sold products & 18 & 3 & 4 & 1 & 231 \\
\hline $\begin{array}{l}\text { Products that } \\
\text { represent } 80 \% \\
\text { of sales }\end{array}$ & 4 & 1 & 2 & 1 & 30 \\
\hline $\begin{array}{l}\text { Number } \\
\text { employees }\end{array}$ & 12 & 7 & 9 & 13 & 85 \\
\hline Revenue US\$ & 2.050 .155 & 1.807 .668 & 2.634 .822 & 6.211 .462 & 14.237 .959 \\
\hline $\begin{array}{l}\text { Return on } \\
\text { sales }\end{array}$ & $4,93 \%$ & $-19,24 \%$ & $-12,55 \%$ & $10,17 \%$ & $1,28 \%$ \\
\hline $\begin{array}{l}\text { Equity } \\
\text { turnover }\end{array}$ & 0,54 & 0,84 & 0,39 & 0,23 & 0,48 \\
\hline $\begin{array}{l}\text { Inventory } \\
\text { turnover } \\
\text { (days) }\end{array}$ & 114,99 & 228,28 & 211,53 & 182,55 & 199,39 \\
\hline $\begin{array}{l}\text { Financial } \\
\text { leverage }\end{array}$ & 0,09 & 0,83 & 0,33 & 0,07 & 0,99 \\
\hline
\end{tabular}

Source: Elaborated by the author.

The sales mix of companies reveals the concentration and the dependence of some products. One can observe that with the exception of company 5, the others depend on a few products for most of its revenue. Based on these characteristics, we will use the expression "generic" for products commercialized in bulk and unbranded. "Product" will be used for the company that sells its own brand 
production. Thus we can characterize two companies that sell exclusively "generic", two companies that sell "generic" and "product", knowing that the "generic" has the largest share of sales, and one company that sells only "product".

The billing amount is in dollar converted by the exchange rate of the end of the year. As it can be observed, company number 5 has a total value of sales greater than the sum of the other companies.

All companies are run by an executive member who was chosen by the other partners.

\section{Research methodology}

The literature on corporate management includes various reasons for the occurrence of mergers and acquisitions ranging from value creation for the company to value destruction resulting from the performance of the managers. Considering the characteristics of the companies and the public to be interviewed composed only by the managers who participated in the process, only the corporate issues that could add value to the new company were investigated. For this investigation, the directors of the companies involved in the merger were interviewed, which, despite being chosen by the other partners, do not own most of the shares of the companies.

To do so, a questionnaire with statements about the new company in a Likerttype scale of five points was prepared and 1 means "strongly disagree" and score 5 represents "strongly agree". The questionnaires were sent in advance to the directors of the companies. Then, a telephone call was made requesting a personal interview. At the time of the interview, the objectives of the research were explained and the questionnaire was applied to each of the directors individually. When requested by the respondent, the questions were explained as to its meaning and purpose.

Based on the answers obtained, the answers were tabulated and the hypotheses were tested with the help of SPSS by using the nonparametric Friedman test.

\section{Analysis of results}

\subsection{Hypothesis 1: The new company will have more market power}

In order to verify the hypothesis, the questions in Table 4 were prepared. According to the literature, the market power of a company may be represented by the product line amplitude and thus the company can have greater market presence, as well as some retail clients may prefer to have a single supplier. The reduction of production costs allows the company to destine more resources to invest in market expansion through the stock market or with lower prices. 
Table. 4. Questions related to market power

\begin{tabular}{l|c}
\hline Statements & $\begin{array}{c}\text { Average } \\
\text { Ranking }\end{array}$ \\
\hline The merger increased the market power of the new company & 3.40 \\
\hline The merger expanded the product line of the new company & 1.90 \\
\hline The merger will allow the reduction of production costs & 3.10 \\
\hline The merger will allow the new company to commercialize & 1.60 \\
\hline
\end{tabular}

Source: Elaborated by the author.

The perception of increasing market power is very strong, as well as the reduction of production costs. However, the expansion of product lines and higher prices did not get a good score from respondents. As it can be seen in Table 4, the lowest level of agreement for the expansion of product line and for the higher prices was given by the companies which commercialize "generic", as previously characterized. The evaluation resulted in a chi square of 8.775 and significance of 0.032. Therefore, the hypothesis that one of the reasons for the merger was to increase the market power is confirmed. The result is more in agreement with studies of Kim and Singal (1993) who confirm the increase in market power with the concentration of companies.

As it can be seen from the results, the managers believe that the new company will reduce production costs and consequently market power. They do not really believe in the expansion of product line and in the increase of prices.

As seen in Table 3 two companies have significant loss, while the other generated income, resulting in an average of $-3.08 \%$ profit on sales. This confirms the expectation of increased market power to improve margins.

\subsection{Hypothesis 2: The new company will obtain scale economies}

The savings resulting from the increase in volume of production, as Demarzo and Berk (2009) stated, can be identified by the elimination of overlapping tasks as sales, distribution, purchasing, among others. According to McGuckin and Nguyen (1995), financial gains and more rational use of resources by consolidating companies may occur.

The questions in Table 5 were used for the verification of hypothesis 2 . 
Table. 5. Questions related to scale economy

\begin{tabular}{l|l}
\hline Statements & $\begin{array}{l}\text { Average } \\
\text { Ranking }\end{array}$ \\
\hline $\begin{array}{l}\text { The merger will allow the most efficient use of resources of the new } \\
\text { company }\end{array}$ & 3.50 \\
\hline The merger will allow scale economy in purchasing & 3.50 \\
\hline The merger will allow scale economies in financial resources & 2.50 \\
\hline The merger will allow scale economies in the commercial area & 3.00 \\
\hline The merger will allow scale economies in product distribution & 2.50 \\
\hline
\end{tabular}

Source: Elaborated by the author

According to the data in Table 5 all managers have expectations for scale economies in purchasing, for efficient use of resources and for the commercial area. The lowest score was on scale economies in financial resources and distribution. Statistical tests resulted in a chi square of 5.714 with a significance of 0.222 rejecting hypothesis 2 .

The activity indicator used was the equity turnover According to the characteristics of the company, described in Table 1, none of the companies has a level of efficiency, do not turn the equity or once a year. Despite confirming the expectation for increasing the efficiency of the use of resources in the new company, the managers did not agree with the economies in the use of financial resources and distribution, rejecting the hypothesis of scale economies.

\subsection{Hypothesis 3: Additional resources will be obtained with the merger}

One of the reasons for mergers is the complementarity of resources under various operational aspects. According to Grinblatt and Titman (2005) the joining of companies can generate operational synergies. According to the characteristics of the companies, this can result in larger orders with suppliers to reduce costs, as well as gains in production scale, finance and other areas. As it is placed in Table 6 , managers were asked about the complementarity of resources in several areas. 
Table. 6. Questions about the complementarity of resources

\begin{tabular}{l|c}
\hline Statements & $\begin{array}{c}\text { Average } \\
\text { Ranking }\end{array}$ \\
\hline $\begin{array}{l}\text { With the merger the companies will complement their purchasing } \\
\text { resources }\end{array}$ & 1.90 \\
\hline $\begin{array}{l}\text { With the merger the companies will complement their production } \\
\text { resources }\end{array}$ & 2.90 \\
\hline $\begin{array}{l}\text { With the merger the companies will complement their financial } \\
\text { resources }\end{array}$ & 3.70 \\
\hline $\begin{array}{l}\text { With the merger the companies will complement their commercial } \\
\text { resources }\end{array}$ & 3.70 \\
\hline $\begin{array}{l}\text { With the merger the companies will complement their distribution } \\
\text { resources }\end{array}$ & 2.80 \\
\hline
\end{tabular}

Source: Elaborated by the author

According to the data in Table 6 the complementarity of resources is very strong mainly in relation to the commercial and the financial area. The tests resulted in a chi square of 9.143 with a significance of 0.058 confirming hypothesis 3.

The companies might complement their resources according to the manager's expectation. The highest ranking was in finances and in the commercial area. The approval of the hypothesis can be explained by the characteristics of the companies. According to Table 1 what can be seen is that most of them had their sales concentrated in a small number of clients and with a small number of commercialized products. The merger might result in dispersion of sales and creation of new products, an apparently surprising result since the companies are in the same market segment and, therefore, have access to the same suppliers and clients. Under the financial aspect it is explainable by the fact that the new company may concentrate its productive activities and may get rid of some assets, so financial resources will be left. The financial indicator used to compare to this hypothesis was the financial leverage, measured by debt capital percentage on capital. As can be seen in Table 1, some companies are very leveraged and others use some third-party capital, the merger of the companies will make this more balanced relationship.

\subsection{Hypothesis 4: The merger will bring corporate benefits}

In the other set of questions the corporate benefits under many aspects were listed, as well as the tax economies, and the use of surplus funds, inefficiencies and diversification were related, as stated by King, Slotegraf and Kesner (2008). In order to check this hypothesis the questions in Table 7 were elaborated. 
Table. 7. Questions about corporate benefits

\begin{tabular}{l|c}
\hline & $\begin{array}{c}\text { Average } \\
\text { Ranking }\end{array}$ \\
Statements & 2.20 \\
\hline The merger will allow tax economies & 2.40 \\
\hline The merger will allow the use of surplus funds & 2.10 \\
\hline The merger will eliminate inefficiencies & 3.30 \\
\hline The merger will allow the diversification of businesses &
\end{tabular}

Source: Elaborated by the author

As it can be seen from the results in Table 7 the elimination of inefficiencies and the diversification of businesses achieved the highest scores. However, the hypothesis must be rejected because statistical tests resulted in a chi square of 3.75 with a significance of 0.290 .

The corporate benefit that achieved the highest ranking was the diversification of businesses and the lowest ranking was about the elimination of inefficiencies. This can be explained by the loss of some tax benefits arising from the revenue increase in the merger of the companies. Thus the hypothesis of larger corporate benefits was rejected. The indicators confirm because the cooperative has some exemptions from taxes and as can be seen in Table 1 the majority of them leverage is small, the great inefficiency is in inventory turnover, for it will be necessary to diversify the business.

\section{Conclusions}

The large number of mergers and acquisitions challenges researchers in search of reasons to justify its occurrence and the results of these movements. Most of the studies seek to identify the financial and the market results or other gains of new companies.

The main studies are conducted in public companies with shares traded on stock exchanges. Mergers with private companies and mainly with cooperatives are more difficult to be studied due to the difficulty in obtaining data and to the strategies involved.

The present study sought reasons from the point of view of presidents of five cooperatives who decided to form a new and unique company. They belong to the same sector of activity and are small companies both in sales volume and in number of employees. Based on the available literature, a questionnaire with four aspects to be analyzed was developed: market power, scale economies, complementarity of resources and corporate benefits.

The responses from the interviews were analyzed using nonparametric statistics and confirmed the hypothesis of increasing the market power and obtaining additional resources. The hypotheses of achieving scale economies and corporate benefits were rejected. 
The answers were compared with the financial indicators of cooperatives, to check whether the expectations of managers agreed with the results of companies that did the management. The responses show that there is harmony between the performance of cooperative and expectations of managers, showing that the merger seeks to improve the results of the five companies.

This study is relevant for several reasons: because it is applied in small cooperatives, therefore, companies that do not have profit as the main goal and no market monitoring which would allow the assessment of the company according to the share price on the market. Therefore, the research did not focus on the value of the companies, but on the reasons or intentions to merge. Thus, no economical and financial data were underlined.

The results show that despite previous studies showed contradictory results the expectation of obtaining greater market power was one of the reasons that emerged with great importance in deciding about the merger. The result can be explained by the structural characteristics of the companies. Only one of them had a service structure to the market with a sales team and a well-established distribution system. The others traded the product in bulk without their own brand to other companies which pack and commercialize the product. Thus, most of them felt they were losing competitiveness. They may change the way they act in the market with the merger. The highest market power is the differential in relation to the capitalist companies, since it shows the desire to extend the benefits to the company and the associates.

Another approved hypothesis was regarding the complementarity of resources. At first, a surprising result considering that cooperatives were active in the same market, using the same raw materials and having access to the same suppliers, and nevertheless, managers believe they will complement their resources. This probably arises from the expectation to sell some assets of the new cooperative which will allow investments in the market and in more modern equipment.

Similarly to previous studies with large public companies, this study with small cooperatives showed similar and conflicting results. It was expected that due to their characteristics, the scale economies would be relevant in the decision to merge. However, in the manager's opinion, this was not the relevant issue, probably by the characteristics of the market segment where it is necessary to produce and industrialize during the harvest and commercialize the product throughout the year. Thus, the savings resulting from the production process are not relevant.

The other corporate benefits were also not considered as important in order for motivating the merger, probably because with the merger and the higher volume of sales, the tax benefits that cooperatives had will remain even with the growth in the volume of sales. Another reason for the rejection of this hypothesis is the difficulty of the people responsible for the management to admit that inefficiencies in the company exist.

Future research might use the same method utilized in this work in order to search mergers and incorporations in private companies with distinct characteristics from cooperatives. The studies conducted in this work could be used to further the reasons for the occurrence of merging in small companies and of different sectors to assess whether the environmental factor can influence the 
process of merging and acquisitions. Future studies could compare the results of mergers between cooperatives, private companies and public companies.

\section{References}

Ansoff, H. (1977) Strategic Management, Palgrave Macmillan, New York. ISBN 978-0230-52548-1.

Bradley, M; Desai, A. y Kim, E.H. (1988) Synergistic gains from corporate acquisitions and their division between the stockholders of target and acquiring firms. Journal of Financial Economics, №. 21, pp. 3-40.

Brealey, R. A. y Myers, S.C. (2006) Corporate finance:Financing and risk management. Porto Alegre. Bookman. ISBN 85-363-0532-0.

Cook, M.L. (1995) The future of U.S. agricultural cooperatives: a neo-institucional approach. American Journal of Agricultural Economics, №.77, pp. 1153-1159.

DeMarzo, P. y Berk, J. (2009) Corporate finance. Porto Alegre. Bookman. ISBN 978-857780-339-2.

Devos, E; Kadapakkam, P. R. y Krishnamurthy, S. (2009) How Do Mergers Create Value? A Comparison of Taxes, Market Power, and Efficiency Improvements as Explanations for Synergies. The Review of Financial Studies, № 22, Vol. 3, pp. 1179-1211.

Drimer, A. K. y Drimer, B. (1973) Las cooperativas. Fundamentos, história, doctrina. Buenos Aires. Intercoop.

Grinblatt, M. y Titman, S. (2005) Financial Markets and Corporate Strategy, 2 ed. Porto Alegre. Bookman. ISBN 978-85-3630-559-2.

Haleblian, J; Devers, C. E; McNamara, G.; Carpenter, M. y Davison, R. B. (2009) Taking stock of what we know about mergers and acquisitions: A review and research agenda. Journal of Management, № 35, Vol. 3, pp. 469-502.

Jensen, M. C. y Ruback, R.S. (1983) The Market for corporate controle the scientific evidence. Journal of Financias Economics, N ${ }^{\circ} 11$, pp. 5 -50.

Ingham, H.; Kran, I. y Lovestam, A. (1992) Merger and Profitability: A Managerial Success Story?. Journal of Management Studies, No 29, pp.195-208.

Kim, E. H. y Singal, V. (1993) Mergers and market power: Evidence from the airline industry. American Economic Review, No 83, pp. 549-569.

King, D.R.; Slotegraf, R. y Kesner, I. (2008) Performance implications of firm resource interactions in the acquisition of R\&D-intensive firms, Organization Science, $\mathrm{N}^{\circ} 19$, Vol. 2, pp. 327-340.

Lubatkin, M.; Schulze, W. S.; Mainkar, A. y Coterril, R. W. (2001) Ecological investigation of firm effects in horizontal mergers. Strategic Management Journal, $\mathrm{N}^{\mathrm{o}}$ 22, pp. 335-357.

McGuckin, R. H. y Nguyen, S. V. (1995) On productivity and plant ownership change: New evidence from the Longitudinal Research Database. Rand Journal of Economics, $\mathrm{N}^{\mathrm{o}} 26$, pp. 257- 276.

Meglio, O. y Risberg, A. (2010) Merger and Acquisitions- Time for a methodological rejuvenation of the Field?. Scandinavian Journal of Management, № 26, pp. 87-95.

Porter, M. E. (1980) Competitive Strategy: Techniques for Analyzing Industries and Competitors. New York: The Free Press. ISBN 0-684-84148-7.

Prager, R. A. (1992) The effects of horizontal mergers on competition: The case of the Northern Securities Company. Rand Journal of Economics, № 23, pp. 123-133. 
Puranam, P. y Srikanth, K. (2007) What they know vs. what they do: how acquirers leverage technology acquisitions. Strategic Management Journal. № 28, Vol. 8, pp. 805-825.

Rhodes-Krop, M. y Robinson, D.T. (2008) The market for mergers and the boundaries of the firm. Journal of Finance, $\mathrm{N}^{\mathrm{o}}$ 63, pp. 1169-1211.

Ross, S.; Westerfield, R. W. y Jaffe, J. F. (1999) Corporate Finance - fifth edition - The McGraw-Hill Companies.

Schneider, J. O. (2012) The Cooperative Doctrine: Analysis of the Reach, the Sense and the Actuality of their Values, Principles and Norms at the Present Times. Revista do centro interdisciplinar de desenvolvimento e gestão social- CIAGS, No 3, Vol. 2, pp. 251-273.

Servós, C.M. y Calderón, N.P. (2013) La Sociedad Cooperativa: motivación y coordinación. Un análisis desde las teorias económicas de la empresa y la economía social. REVESCO. Revista de Estudios Cooperativos, № 110, pp. 192-22. DOI: 10.5209/rev_REVE.2013.v110.41440.

Seth, A.; Song, K.P. y Pettit, R.(2002) Value creation and destruction in cross-border acquisitions: An empirical analysis of foreign acquisitions of U.S. firms. Strategic Management Journal, No 23, pp. 921-940.

Trautwein, F. (1990) Merger Motives and Merger Prescriptions. Strategic Management Journal, No 11, Vol. 4, pp. 283-295.

Zylbersztajn, D. (1994) Organization of cooperatives: challenges and trends. Journal of Administration, $\mathrm{N}^{\circ}$ 29, Vol. 3, pp. 23-32. 